\title{
THE ANALYSIS OF FANTASY GENRE'S FORMULA ON HARRY POTTER SERIES
}

\author{
Risa Ambariski
}

\begin{abstract}
This study aims to discover and analyze the formula of fantasy genre that can be found in the seven books of Harry Potter. This is a qualitative study, focusing the research on the particular literary pieces only. This study uses genre theory as the approach in order to fulfill its objective. Genre theory is commonly used to analyze popular fiction which is appropriate to do formula analysis. As the result of this study, there are at least seven formulas of fantasy genre can be found in the series of Harry Potter. Most of those formulas are regularly appear in fantasy stories, especially in popular fiction.
\end{abstract}

Keywords: popular, fantasy, genre, formula, Harry Potter

\section{Intisari}

Penelitian ini bertujuan untuk menemukan dan menganalisa formula dari genre fantasi yang bisa ditemukan dalam tujuh buku Harry Potter. Penelitian ini adalah penelitian kualitatif. Penelitian difokuskan pada karya sastra yang tersebut secara khusus. Penelitian ini menggunakan teori genre sebagai pendekatan untuk memenuhi tujuan dari penelitian ini. Teori genre biasa digunakan untuk meneliti fiksi populer dan sangat tepat untuk melakukan analisa terhadap formula. Sebagai hasil dari penelitian ini, setidaknya ada tujuh formula dari genre fantasi yang bisa ditemukan dalam serial Harry Potter. Sebagian besar dari formula tersebut sering muncul dalam cerita-cerita fantasi.

Kata kunci: populer, fantasi, genre, formula, Harry Potter

\section{INTRODUCTION}

The series of Harry Potter tells about the struggle of a boy named Harry Potter to defeat an evil wizard called Lord Voldemort. Lord Voldemort is a cruel heartless wizard who has murdered many people, wizards and non-wizards. He even kills his own followers, people who praise him, without showing mercy when they make him disappointed or are disobedient to him. Harry, whose parents are also killed by Voldemort, and who is the only one who can retain from Voldemort's deadly curse when he is a baby, tries to stop Voldemort's evilness.
All series of Harry Potter are categorized as popular literature. Popular literature is a product of popular culture. Nachbar and Lause (1992) said that there are three kinds of culture. They are folk culture, elite or high culture, and popular culture. Folk culture is defined as a culture that is created and developed through ages among a limited community and communicated directly from generation to generation. Elite or high culture is a culture that is created by and for those limited people who have specifications in interests, training, or knowledge, not common people. 
Then popular culture is a culture in form of goods and activities that are created for and consumed by not by the elite people but common people, the masses. The stories of Harry Potter belongs to the last category because it is produced for masses and simply does not belong to folk or high culture because it is not a story that passed by from generation to generation or being enjoyed only by specific kind of people.

Popular fiction has gained its reign in literary world. In spite of all the fact about it, popular literature or commonly called popular fiction becomes an important field to being studied or discussed nowadays. In recent years, there has been an increasing interest in studying popular literature. Adi (1992:1) describes a study on popular literature as a serious, respectable, necessary, and important field of inquiry.

There are many researches and studies analyzing popular literature today because of its importance among the readers and society. Particularly in Universitas Gadjah Mada, the studies of popular literature show an increase of researchers' interest toward popular literature.

Fantasy is one genre in popular literature. Fantasy is a form of literature which fuses the reality and imagination which has no relation with the real-world. In fantasy story, there are fantastic creatures and places, witches or wizards, and other extraordinary things that actually do not exist in real-world. Real-world is the world where people, ordinary people lives, eating, walking, sleeping, doing common human activities. Fantasy is an imagination world where human could interact with fantastic creatures, wandering and strolling to an extraordinary fantastic place, or throwing spells and being cursed by a witch. Fantasy is the highest creativity of human's imaginations.

The reason why this particular study is conducted is the importance of popular literature and the limited study toward the formula of fantasy genre. Hopefully, this particular paper would give a significant contribution toward following studies about fantasy genre and also fantasy formula. The major objective of this study is to investigate and analyze the formula of fantasy genre in the series of Harry Potter. Furthermore, along with those objectives before, this study is also trying to reveal how the formula builds the story in the whole series of Harry Potter.

Since the subject of this study is fantasy genre and the purpose is to find and analyze the formula, theory of genre is considered as the best approach that should be used in this particular study. This approach is applied because a particular literary work itself could not be separated from previous work in the same genre, in this case fantasy. In order to find the formula, there are some similarities and differences that have to be classified.

This study is a library research. The sources of this study are taken from written materials in the library. The primary data of this study is the whole series of Harry Potter which is consisted of seven books. The secondary data are theories related to popular and fantasy genre. This study also uses some references taken from electronic sources such as e-book or some articles taken from the internet in order to get a different point of views and also to get a clearer understanding about the subject. The materials, including books 
and electronic sources are chosen because they have important relation and contribution toward this particular study. The data are collected through some close reading toward the books. And then the data are gathered and classified into several parts by comparing the similarities and differences from the elements that appear in the books.

The overall structure of this article takes the form of eight parts which are divided by each formula that is found on the research, those are: (1) an ignorant beginning, (2) the space movement, (3) inheritance of power, (4) the power of prophecy, (5) the hero's extraordinary power, (6) the triumphant of the hero, and (7) the formula of gothic atmosphere. Those seven formulas are described in the following parts.

\section{An Ignorant Beginning}

Usually, the story in fantasy genre commonly starts with the ignorance, the lack of knowledge of the hero's real identity. The hero often comes as an orphan, has no parents, or being raised not by his parents. $\mathrm{He}$ has no knowledge about any magical thing or fantastical thing or whether there is another world beside his current normal daily life. He never knows his true identity until somehow he learns about their history. This formula can be found for example in J.R.R. Tolkiens' The Lord of the Rings. The hero, Frodo Baggins, is raised by his uncle because he has no parents. It also appears in Christopher Paolini's Eragon. Eragon, the hero, is also an orphan who brought up by his uncle. This formula is adopted in Harry Potter series.

In Harry Potter, Harry is an orphan who lives with his uncle, aunt and cousin, the
Dursley family, since the death of his parents. He has to live with the Dursleys because his aunt, his mother's sister, is his only relative. His aunt and uncle told him that his parents died because of a car accident. Under the nursery of his uncle and aunt Harry is raised as an ordinary boy. He looks as well as other kid in the neighborhood.

However, of course, Harry is actually a wizard. His parents, who already passed away, are wizards too. His aunt and uncle never reveal this fact to him because they are afraid and they regard everything related with magic is shameful. Having a wizard in their family is a disgrace. They never let Harry know about the truth behind his parents' death and banned him from everything magical. His aunt and uncle hate everything that sounds unusual or unnatural, including magic. This act of neglect from his uncle and aunt is indicated when Harry shows everything unusual or irrational that only has one explanation, magic. For example, when Harry tells his uncle that he dreams about a flying motorcycle, his uncle gets so mad and angrily tells him that it is impossible.

'... roaring along like maniacs, the young hoodlums,' he said, as a motorcycle overtook them.

'I had a dream about a motorcycle,' said Harry, remembering suddenly. 'It was flying.'

Uncle Vernon nearly crashed into the car in front. He turned right around in his seat and yelled at Harry, his face like a gigantic beet with a mustache: 'MOTORCYCLES DON'T FLY!'1

His aunt and uncle keep this secret until Harry gets a message explaining that he

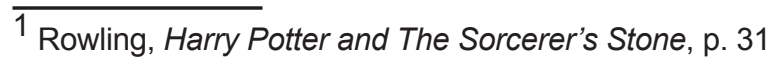


is accepted in Hogwarts School of Witchcraft and Wizardry, a school for a young wizard just exactly like him, the place where his ordinary life will change into the extraordinary one. However, at this point, his uncle still does not want to tell him the truth, and Harry just keeps asking about his true identity.

The ignorance is not only caused by his aunt and uncle but also from Harry's own denial about the fact that he is a wizard. When Hagrid comes to deliver him a letter from Hogwarts, hand to hand, explaining that he is accepted in Hogwarts, he feels so stupid because he does not know anything about what Hagrid has just told him. When he finally figures out that he is actually a wizard, he shows his disbelief and thinks that it must be wrong because he has always been bullied by the Dursleys for his life time. Harry does not know at all that he is, or his parents are, wizards. $\mathrm{He}$ is shocked by this very fact which seems unbelievable for him. His common sense is fighting inside his mind, 'A wizard? Him? How could he possibly be? He'd spent his life being clouted by Dudley, and bullied by Aunt Petunia and Uncle Vernon.'2

The ignorance makes Harry does not have a hint about strange things that often happen in his life. For example, one day Harry finds himself unexpectedly in his school roof when Dudley's gang chases him. He does not know how he gets there. Another example is when his aunt tries to cut his messy hair, and Harry thought that the cutting was horrible. His hair grows exactly the same shape as before the cutting in the next day. He wonders why those strange things happen to him, but because of

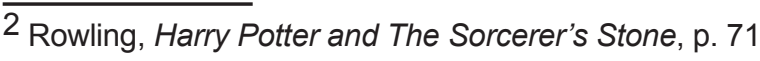

his ignorance, he never knows who he truly is.

In the beginning of the story, Harry Potter is simply an ordinary boy, with the Dursleys and the environment around him. Strange things, or magical things, often happen to him. However because of his ignorance, which is caused by his aunt and uncle's neglect about wizarding world and magical things, he does not aware about the "other world" that also exist.

The ignorance beginning is essential in fantasy story. It arouses the enthusiasm of the readers toward the story. The feeling when the hero's life suddenly changes, from something ordinary becomes the extraordinary, moves the readers. If the hero is already someone that he meant to be since the beginning, a great person naturally, the readers will not feel the emphasis of the story. That is why it is important in fantasy story to have the hero who starts with knowing nothing about his true identity, so then he can move from his ordinary life and change into the life that he never expect before.

\section{The Space Movement}

It has been generally understood that after the hero in a fantasy story experiences the change on his ordinary life, he then moves from his usual circumstance and enters an entirely different environment and custom, from his daily life to another extraordinary state of being. The formula of switching from an ordinary to the extraordinary does not only happen in fantasy genre, it also commonly appears in adventure genre, because the adventure sometimes becomes the part of fantasy story too. Cawelti mentioned that 
'specific adventure formulas can be categorized in terms of the location and nature in the hero's adventures.' ${ }^{3}$ Every hero in the story has to leave his house or his normal life and welcoming the new world with the challenge that he has to face.

Harry has lived his entire life with the Dursleys in Privet Drive. For eleven years, all that he knows is only the neighborhood of his uncle's house. However, it only last until he found out who he really is, a wizard. In the wizarding world, particularly in England according to the setting of the story, every witch and wizard who turns eleven is accepted in Hogwarts School of Witchcraft and Wizardry to study about magic. And so it does with Harry. After receiving the letter from Hogwarts, Harry is ready to enter the world which he never knows before.

The changes in the hero's ordinary life at least can be seen from two aspects: the environment and the habit or experience. The hero firstly moves into another environment and in the new place he experience new way of living and learns some new information. It happens in Harry Potter.

The first change is on the environment where Harry lives. In Harry Potter, the wizarding world (where magical things possible to happen) and the Muggle world (the ordinary people, non-wizard world) are exist side by side to each other. However, the Muggles (common people, non-wizard) do not know about the existence of the wizarding world. There are some boundaries between those worlds to avoid Muggles from the wizarding world. If in The Chronicles of Narnia: The

3 Cawelti, 40
Lion, the Witch, and the Wardrobe, the Pevensies enter Narnia through the old wardrobe in Prof. Kirke's house, Harry enters the wizarding world through the wall of Platform Nine and Three-Quarters in King's Cross station. It is impossible though that there is a Platform Nine and Three-quarters in a station, and Harry is confuse too when he goes there for the first time. However in the wizarding world, everything is possible, and by passing the platform, he comes to the magical world.

And he comes to Hogwarts, where many magical things happen and Harry practically studies and uses magic. He learns many things and discovers more than he ever expects to know about magic and wizarding world. He finds many fantastic creatures such as dragon, unicorn, three-headed dog, mermaid, and many other creatures. Here he experiences the change of his ordinary life habit. If in the Dursley's house he is often being bullied by the Dursleys, in wizarding world Harry find himself very famous. For example when he enters The Leaky Cauldron, a wizard bar, people are shaking his hand and seems very glad to see him after Hagrid tells the people that he is Harry Potter. It is because he is the only one who can rescue from Voldemort when he was a baby, and people regard him as hero because Voldemort lost his power after he tried to kill Harry.

The movement in fantasy genre is needed to make the readers feel the difference between the ordinary and extraordinary. It is important in fantasy story because the hero should move from the usual into the unusual and the readers need to know that from that moment, the hero's journey is going to start. This movement becomes the formula of fan- 
tasy genre. As in Spider-Man, in which Peter Parker change from a geek man into a superhero after being bitten by a spider, the letter from Hogwarts explaining that Harry is a wizard change Harry's life. From an unworthy person in Dursley's house, he becomes the only one who later can save the wizarding world from the evilness of Voldemort.

\section{Inheritance of Power}

In several fantasy stories, it is being told that the hero inherits the power or skill from his ancestors (his parents or his grandparents or his grand grandparents). The hero in fantasy story usually is a descendant from a particular person (or wizard) in the past. The ancestors are (often) famous and they are included as prominent figure in their era. This is also what happens with Harry. For his entire life, Harry only knows that his parents died because of a car accident and that is also how Harry got his scar. However it turns out that his parents were killed by Voldemort whom actually tried to kill him too.

After his long discovery about his parents, he finds that his parents were great wizards who were famous too. His father and mother were Head Boy and Head Girl ${ }^{4}$ when they were students at Hogwarts as Hagrid says, 'Now, yer mum an' dad were as good a witch an' wizard as I ever knew. Head boy an' girl at Hogwarts in their day!'5 One of his teachers tells him that his mother was a very smart girl, although she is a muggle-born. Muggle is a

$4 \quad$ Head Boy and Head Girl are the term for a couple students of boy and girl in the seventh grade at Hogwarts who are responsible for the rest of the students. They are chosen because of their outstanding performance in school from their first until sixth grade.

5 Rowling, Harry Potter and The Sorcerer's Stone, p. 68 term for non-wizard people, ordinary people who does not do magic. Muggle-born is a term that is being used to mention a witch or wizard who has muggle parents. Meanwhile, his father was a smart and popular boy at his age in Hogwarts too. He was also the captain of the quidditch team of Gryffindor, the house where Harry also belongs, like what Professor McGonagall said to him: 'Your father would have been proud,' she said. 'He was an excellent Quidditch player himself.' ${ }^{\prime}$ His parents are also two of the founder of the Order of the Phoenix, an organization that is made to fight against Voldemort and his followers.

So Harry basically inherits his quidditch skill from his father, makes him one of the best quidditch player in Hogwarts. Besides that he also inherits the smartness from his mother. However, above all, he inherits the power that lies in his blood from his mother. As Dumbledore says, his mother gave him the most powerful protection when she stood between Voldemort and Harry in the night Voldemort tried to kill him. The charm will protect Harry as long as he stays under the guarding from his mother's blood, in this case his aunt. That is the reason why Harry was left in his aunt's house after the death of his parents while there are so many wizard families who want to take care of him. The shield that lies in his blood is the strongest, ancient shield that protects him from Voldemort, just as Dumbledore says, 'While you can still call home the place where your mother's blood dwells, there you cannot be touched or harmed by Voldemort.'7

$6 \quad$ Rowling, Harry Potter and The Sorcerer's Stone, p. 188

7 Rowling, Harry Potter and The Order of the Phoenix, p. 737 
It is obvious that James and Lily Potter are great wizards. And not only great wizards, they are also famous among the wizarding world. The fact does not end there yet. When the story comes to an end, in the seventh book, Harry discovers that he is the descendant of Ignotus Peverell, one of the three Peverell brothers who were the original owners of the Deathly Hallows which being told in the seventh book, Harry Potter and the Deathly Hallows. Harry discovers this fact because he realizes that his Invisibility Cloak is literally the cloak that is being described in the Tale of the Three Brothers (one of wizarding kids' stories), a cloak that have been inherited in generations, from parents to children.

'The Cloak, as you know now, traveled down through the ages, father to son, mother to daughter, right down to Ignotus's last living descendant, who was born, as Ignotus was, in the village of Godric's Hollow.'

Dumbledore smiled at Harry.

'Me?'

'You.'8

The hero has to inherit the power because if he does not, he will not be able to become the hero who has to conquer the evil. The inheritance of power can be seen also in some fantasy stories, for example in Superman. Clark Kent inherits the power that he brings from his origin, Krypton planet, makes him a superhero called Superman. In The Lord of the Rings, Frodo inherits his uncle's ring which make him inherits the duty to destroy the ring to save the world. Percy Jackson,

8 Rowling, Harry Potter and The Deathly Hallows, p. 572 the hero from Rick Riordan's The Lightning Thief, inherits his power from his father, the Greek god Poseidon. Those fantasy stories adopt the same formula in which the hero inherits the power from their ancestors, similar with Harry Potter. It proves that Harry Potter belongs to fantasy genre because it has the formula of fantasy genre.

\section{The Power of Prophecy}

Prophecy usually has a significant part in fantasy story. Every hero (or heroine) in fantasy story always bear a destiny about him in his life. Most of the heroes do not know about the prophecy until they grow older and some of them discover it by themselves. The prophecy tells about the hero and the villain of the story that he has to defeat in order to bringing peace toward the world. The hero is being told as the only one who can banish the evil power of the villain (could be a monster, or wicked witch or wizard, or a dark lord). The villain is being described as the one who has made people suffer for such a long time.

The prophecy is important in fantasy genre. It is because prophecy is strongly related with magic. Magic is hardly parted from fantasy, because the magic itself is a fantasy. People in the past believed about prophecy, for example the Greek who strongly believe in prophecy which is reflected in their stories. Besides that, the readers need to know how the villain will be conquered, and by whom. They want to know what is going to happen with the story they read. They have to be ensured. When the hero is about to come, there is a prophecy predicts the birth or the coming of the hero. For example in The Chronicles of Narnia, there is a prophecy said that the 
power of the wicked witch will be vanished if there are two sons of Adam and two daughters of Eve fill the thrones of Cair Paravel. In Harry Potter, there is a similar formula.

Harry was born with a different destiny with other people. When he was still a baby, Voldemort himself tried to kill him. Voldemort actually rarely kills people by himself. Although he is evil he does not kill many people. His followers do it for him. However, there is an exception when he chooses certain people he wants to kill himself. Those people whom he cannot entrust to be killed by his followers. Harry is included in those exceptions. As he grows older, Harry starts wondering the reason why Voldemort tried to kill him when he was a baby. He keeps asking Dumbledore why Voldemort tries to kill him. Dumbledore does not let him know about the reason until he considers that Harry is old enough to know all the fact about his relationship with Voldemort.

And then after Harry faces Voldemort for the fourth time, watches Voldemort literally rises and owns a solid body, and after he experiences his fellow and his Godfather's death, Dumbledore finally tells him about the connection between Harry and Voldemort. He tells him the reason why Voldemort tried to kill him when he was a baby. It is because a prophecy, prophecy about the fall of Voldemort. The prophecy says that there is a baby who has just been born with a destiny to conquer the Dark Lord or Voldemort. The oracle, who happen to be a teacher of Hogwarts said this prophecy to Dumbledore,

'The one with the powers to vanquish the Dark Lord approaches... born to those who have thrice defied him, born as the seventh month dies... and the Dark Lord will mark him as his equal, but he will have power the Dark Lord knows not... and either must die at the hand of the other for neither can live while the other survives... the one with the power to vanquish the Dark Lord will be born as the seventh month dies...'?

It means that the only person who can defeat Voldemort is born in the end of July from parents who have defied Voldemort three times. This prophecy actually does not only refer to Harry but also to Neville Longbottom, one of Harry's friends in Hogwarts, whose parents have escaped and defied Voldemort three times and was born on the end of July too. However, Voldemort has chosen Harry and marks him as his opponent.

There is always a prophecy about the hero in fantasy story, or in other words, the hero has a certain destiny that he has to bear in his life. This is why the prophecy becomes the formula in fantasy story. Although the content of the prophecy does not identical, but all of them imply that the hero will be the one who can save the world from the suffering caused by certain reason.

\section{The Hero's Extraordinary Power}

It is very common that the hero in fantasy stories has the power that is rarely own by anyone else. It does not mean that he is always stronger than all other characters in the story. In fact, the heroes are not the strongest persons in the story indeed, but he has a special power that he has above those people. $\mathrm{He}$ has the power that anyone else does not have. This power sometimes connects the

9 Rowling, Harry Potter and The Order of the Phoenix, p. 741 
hero directly with the villain too, and that is what happens in Harry Potter. Harry is not the strongest wizard ever in the wizarding world. Voldemort is definitely much stronger than he is. However, he has power that can defeat Voldemort.

From the incident when Voldemort tries to kill Harry as a baby, Harry gains some powers that he brings until he grows up. As it is said by the prophecy, 'and the Dark Lord will mark him as his equal, but he will have power the Dark Lord knows not..., Voldemort inadvertently transfers his power to the baby Harry. It resulted with Harry's ability to speak with and understand snake's language. He becomes a Parselmouth. He once talks to a snake in the zoo and accidentally releases it from its stall in the first book. He understands about his power in his second year at Hogwarts, when he unconsciously speak with snake in a duel club at Hogwarts, and Ron confronts him after that,

... Then Ron pushed Harry into an armchair and said, 'You're a Parselmouth. Why didn't you tell us?'

'I'm a what?' said Harry.

'A Parselmouth!' said Ron. 'You can talk to snakes!'

'I know,' said Harry. 'I mean, that's only the second time l've ever done it. I accidentally set a boa constrictor on my cousin Dudley at the zoo once - long story - but it was telling me it had never seen Brazil and I sort of set it free without meaning to that was before I knew I was a wizard -‘

'A boa constrictor told you it had never seen Brazil?' Ron repeated faintly. ${ }^{10}$

10 Rowling, Harry Potter and The Chamber of Secrets, p. 212
Another unexpected power is the mind connection between Harry and Voldemort which makes Harry able to see inside Voldemort's mind sometimes, and Voldemort as reverse can enter Harry's mind too. In the last book, Harry discovers the fact that there is part of Voldemort's soul inside him, from which he gets Voldemort's ability upon him. That is all mentioned in the prophecy before, about Harry who will become the only person who can conquer the power of Voldemort and that he will have the power that people, even Voldemort, never expect.

One more power that Harry owns, often being told by Dumbledore, is love. Voldemort is full with hatred, knows no love in his life. He even does not feel the love from his mother because his mother died right after she given birth to him. On the other hand, Harry is filled with love, from his parents before they died, from his friends, from his mentors, from his Godfather, they love Harry so much. Eventhough there are some people who hate him such as the Dursleys or Snape, the power of love in his life is undeniable. The best proof and obvious of love that Dumbledore always reminds to Harry are his mother who sacrificed her life to protect him when he was about to be killed by Voldemort when he was a baby. From her protection, Harry can retain from Voldemort and remains alive until he grows up.

'Your mother died to save you. If there is one thing Voldemort cannot understand, it is love. He didn't realize that love as powerful as your mother's for you leaves its own mark. Not a scar, no visible sign ... to have been loved so deeply, even though the person who loved us is gone, will give us some protection forever. It is in your very skin. Quirrell, full of hatred, greed, and ambition, sharing his soul with 
Voldemort, could not touch you for this reason. It was agony to touch a person marked by something so good.'11

The extraordinary power that lies in the hero does not have to be a physical strength like a powerful magical spell or else. It could be something that his villain does not have. From Voldemort's attack, Harry got his ability to understand and speak with snake and he has a mind connection with Voldemort that makes him know about what Voldemort is going to do or thinking. Above all, he has a love, a weapon that always protects him along his life that Voldemort does not have. This is one of the formulas in fantasy genre. The hero has an extraordinary power.

\section{The Triumphant of the Hero}

Maybe the most common and obvious formula in every story, in fantasy genre particularly, is the duel between the hero versus the evil of the story. Jackson (1981:49) says,

Themes can be clustered into several related areas: (1) invisibility, (2) transformation, (3) dualism, (4) good versus evil.

Moreover, Jackson adds that in fantasy story, the evil comes in many ways. There are many forms of evil in fantastic story, depends on the cultures. It can have a very terrifying image, the one who has made all people suffering, or it might comes as an ordinary human being,

The concept of evil, which is usually attached to each other, is relative, transforming with shifts in cultural fears and values . . . A stranger, a foreigner, an outsider, a social deviant, anyone speaking in an unfamiliar language

11 Rowling, Harry Potter and The Sorcerer's Stone, p. 371-372 or acting in unfamiliar ways, anyone whose origins are unknown or who has extraordinary powers, tends to be set apart as other, as evil.

In the series of Harry Potter, the evil has incredible power and no one but the hero can defeat him. It really needs a great effort from the hero before he finally can conquer the evil, just as the readers can see through the series. Harry as the hero should beat the evil, a wicked wizard named Lord Voldemort. He is the only one who can conquer Voldemort because he is destined to do it. However, his struggle is not that easy. Harry has to face him several times before he can finally defeat him at all. He faces him in the first, second, fourth and fifth book before Voldemort finally dies in the seventh when Harry successfully conquers him.

In Harry Potter, Harry faces Voldemort not only for one or two times but five times, without mentioning their meeting when Harry is still a baby. It is in the first, second, fourth, fifth, and seventh book. In the third and sixth book, Harry does not deal with Voldemort directly although Voldemort still becomes his true enemy. In every book, Voldemort comes in some different ways and manners.

The seventh book becomes the last effort from Harry and Voldemort to fight each other because there is only one of them who can live and the other must die. Harry learns that there is a flaw in Voldemort's plan on killing him. He figures out the flaw and uses it as a weapon to defeat Voldemort. Harry told Voldemort about his fatal flaw, 'That wand still isn't working properly for you because you murdered the wrong person. Severus Snape was never the true master of the Elder 
Wand. He never defeated Dumbledore.' ${ }^{12}$ As their spells collide in the air, Harry's spell wins upon Voldemort's and Voldemort dies, forever now. The good side wins upon the evil.

After he beats Voldemort, Harry, and so the rest of the wizarding world, live harmlessly, safely, and peacefully without the threat from Voldemort who already dies. He gets married and has three children. His scar never bothers him again. Everyone lives happily ever after. The hero overcomes all odds and brings happiness and peacefulness to the world. The result of conquering the evil, the hero's life is back again into normal. He does not have to fight or going for a quest anymore.

\section{The Formula of Gothic Atmosphere}

Harry Potter, although classified as fantasy genre, is not a straight strict fantasy. It follows the formula of general fantasy story, but the author gives the readers some refreshments by adding other elements in the story. As Cawelti says that a formulaic work will be unique when 'it brings a new element into the formula, or embodies the personal vision of the creator.' Then, in order to differentiate the story with other fantasies, the author adds the atmosphere of gothic in the story. The gothic atmosphere is reflected by the presence of Halloween day and the contradiction on the glee of Christmas in most of the books.

Halloween day in Western culture is celebrated as the day when spirits of the dead people can walk into the world. People say the spirits are imprisoned during the ordinary days, but in Halloween day, they can walk

12 Rowling, Harry Potter and The Deathly Hallows, p. 594 pass the gate between human's and spirits' world into human world. In horror story, which is the derivation of fantasy genre, Halloween day becomes the most commonly used setting of time. Harry Potter does not belong to horror story because it has different structure with horror story particularly. However, it adopts the murky tone of Halloween.

First of all, the murder of Harry's parents by Voldemort happens in Halloween night. When Voldemort tries to recall this memory in his head, Harry can see it too from his mind,

The night wet and windy, two children dressed as pumpkins waddling across the square, and the shop windows covered in paper spiders, all the tawdry Muggle trappings of a world in which they did not believe ... And he was gliding along, that sense of purpose and power and rightness in him that he always knew on these occasions ... not anger ... that was for weaker souls than he ... but triumph, yes ... he had waited for this, he had hoped for it ...

\section{'Nice costume, Mister!'}

He saw the small boy's smile falter as he ran near enough to see beneath the hood of the cloak, saw the fear cloud his pained face: then the child turned and ran away ... ${ }^{13}$

Although Voldemort does not mention about Halloween in his mind, the setting of environment surrounds him clearly shows how a Halloween night is supposed to be. The two children who dress as pumpkin, the paper spiders that cover the windows, and the boy who shouts 'Nice costume, Mister!' to him because he uses cloak commonly used by wizard with the hoodie, are evidences that

13 Rowling, Harry Potter and The Deathly Hallows, p. 280 
the scene happens in Halloween night. There is a more obvious proof that the incident happened in Halloween night. It is from the sign in front of the wreck that once was Harry's house,

On this spot, on the night of 31 October 1981, Lily and James Potter lost their lives. Their son, Harry, remains the only wizard ever to have survived the Killing Curse. This house, invisible to Muggles, has been left in its ruined state as a monument to the Potters and as a reminder of the violence that tore apart their family. ${ }^{14}$

The creepiness of Halloween appears in the other books too. In the first book, a Troll, an ugly and stupid semi-giant creature, suddenly hangs around inside the castle in the Halloween night and it causes some troubles for the whole school. In the second book Harry starts to hear strange voices that anyone else cannot hear. Then it leads him, firstly in the Halloween night, to the body of a cat called Miss Norris which is stoned and stiff, hanging on its tail, and a message that spreads fear into the whole school. The Halloween night in the third book becomes the moment when Sirius Black, an escape prisoner from Azkaban, is trying to come through Gryffindor's common room. The incident grows anxiety that night among the people at Hogwarts. This Halloween formula does not appear either in the fifth book, or in the sixth. However some important events still happen in around October-Halloween is at 31 October. However it still becomes a patent formula for the whole series of Harry Potter.

14 Rowling, Harry Potter and The Deathly Hallows, p. 272
The contradiction on the glee of Christmas becomes part of the gothic atmosphere. Christmas is identical with joy and happiness. Many people write the story about Christmas in sort of magical and fantastic way. A Christmas Carol, The Little Match Girl, and The Polar Express are some stories that promote the magic of Christmas. They are classified as fantasy story too. All those stories tell about the magic of Christmas. Christmas is being described as a moment full of joy, kindness, and happiness. Even a girl in the story of Little Match Girl feels the joy of Christmas although she was in a condition of hunger and suffering and finally died in the end of the story.

On the other hand, as a fantasy, the series of Harry Potter have its own way to celebrate Christmas. Similar with the Halloween formula, the Christmas formula in Harry Potter also has such important role on the story because it is strongly related with the main conflicts in all books. However, in Harry Potter, the image of Christmas does not always appear in a happy and joyful state. Here, the story shows some contradiction with the sorrow and gloomy atmosphere, sometimes scary and tense.

The evidence of this formula is presented in the fifth book when an awful incident happens few days before Christmas in the fifth book. Arthur Weasley, Ron's father, is attacked by Voldemort's snake while he is on duty for the Order's task. He is dying because of this attack. This is horrible for Harry because he experiences how Mr. Weasley is being attacked inside his mind and he sees it through the eyes of the snake. The Christmas becomes much tenser and gloomier in the seventh book when Harry is nearly killed 
by Voldemort in Godric's Hollow, the village where Harry was born. Luckily he can slip from Voldemort at the last second.

The gloomy atmosphere is represented by the graveyard. In Christmas Eve, when people supposed to gather with their family, Harry visits his parents' grave in Godric's Hollow. That is the first time he visit his parents' tombs and he is overwhelmed by it, as it is showed from the paragraph below,

... And tears came before he could stop them, boiling hot then instantly freezing on his face, and what was the point in wiping them off or pretending? He let them fall, his lips pressed hard together, looking down at the thick snow hiding from his eyes the place where the last of Lily and James lay, bones now, surely, or dust, not knowing or caring that their living son stood so near, his heart still beating, alive because of their sacrifice and close to wishing, at this moment, that he was sleeping under the snow with them. ${ }^{15}$

The setting of place emphasizes the gloomy atmosphere, supported by the incidents that happen at the moment. The formula of gothic atmosphere differentiates Harry Potter from another fantasy story. Harry Potter still belongs to fantasy genre, but the gothic atmosphere gives the reader some refreshment so the reader will not get bored with the common structure that regularly happens in another story in the same genre, fantasy.

\section{CONCLUSION}

The research shows that there are formulas that commonly appear in fantasy genre,

15 Rowling, Harry Potter and The Deathly Hallows, p. 269 those are: an ignorant beginning, the space movement, inheritance of power, the power of prophecy, the hero's extraordinary power, the triumphant of the hero, and the formula of gothic atmosphere. These formulas appear in almost every book and become its regular formula and important parts of the story.

The formulas in Harry Potter make this story belongs to fantasy genre, particularly, popular fantasy genre. The formula becomes the foundation of the storyline, makes the story to be a formulaic story that is loved by the readers. However, although the author keep maintains the general formula of fantasy story, she gives some improvements to the story by adding several formulas out of the generals. By doing this, the story becomes more interesting and the readers find another pleasure when reading the story.

\section{REFERENCES}

Adi, Ida Rochani. Fiksi Populer: Teori dan Metode Kajian. Yogyakarta: Dunia Pustaka. 2010.

- Pendekatan Psikoanalisis dalam Kajian Sastra Populer Amerika. Yogyakarta: Gadjah Mada University Press. 1992.

Bloom, Clive. Best Seller: Popular Fiction since $19002^{\text {nd }}$ Edition. London: Palgrave Macmillan. 2008.

Cawelti, John G. Adventure, Mystery, and Romance: Formula Stories as Art and Popular Culture. Chicago: University of Chicago Press. 1976.

Gans, Herbert J. Popular Culture and High Culture: An Analysis and Evaluation of Taste. New York Basic Books, inc. 1974.

Jackson, Rosemary. Fantasy: The Literature of Subversive. London and New York: Methuen. 1981.

Mukerji, Chandra, and Michael Schudson, eds. Rethinking Popular Culture, Contemporary Perspectives in Cultural Studies. California and England: University of California Press Berkeley and Los Angeles. 1991. 
Nachbar, Jack and Kevin Lause (eds). Popular Culture: An Introductory Text. OH: Bowling Green State University Popular Press. 1992

Rowling, J.K. Harry Potter and the Sorcerer's Stone. New York: Scholastic Inc. 2001.

Harry Potter and the Chamber of Secrets. London: Bloomsbury. 1998.

Harry Potter and the Prisoner of Azkaban. London: Bloomsbury. 1999.

Harry Potter and the Goblet of Fire. London: Bloomsbury. 2000.
Harry Potter and the Order of the Phoenix. London: Bloomsbury. 2003.

Harry Potter and the Half Blood Prince. London: Bloomsbury. 2005.

Harry Potter and the Deathly Hallows. London: Bloomsbury. 2007.

\section{Electronic Source}

New Oxford American Dictionary. Electronic Dictionary for Apple MacBook Pro. 